Biol. Stud. 2009: 3(3); 5-16 • DOI: https://doi.org/10.30970/sbi.0303.054

www.http://publications.Inu.edu.ua/journals/index.php/biology

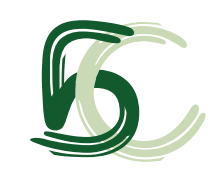

UDC 577.218+616-006

\title{
COMPARATIVE STUDY OF EXPRESSION OF ADAPTOR PROTEINS RUK/CIN85 AND CD2AP/CMS IN NORMAL AND TUMOR HUMAN UTERUS TISSUES
}

\author{
O. I. Basaraba', Ya. P. Bobak', H. Yu. Shuvayeva², \\ O. M. Mayevska ${ }^{2}$, N. I. Igumentseva', S. M. Marchenko',
} N. A. Volodko ${ }^{3}$, V. L. Buchman ${ }^{4}$, L. B. Drobot ${ }^{1}$

${ }^{1}$ Palladin Institute of Biochemistry, NAS of Ukraine, 9, Leontovich St., Kyiv 01601, Ukraine ${ }^{2}$ Institute of Cell Biology, NAS of Ukraine, 14-16, Drahomanov St., Lviv 79005, Ukraine ${ }^{3}$ Danylo Halytsky Lviv National Medical University, 69, Pekarska St., Lviv 79010, Ukraine ${ }^{4}$ Cardiff School of Biosciences, Cardiff University, Cardiff CF10 3US, United Kingdom e-mail:drobot@biochem.kiev.ua

Adaptor proteins play an important role in facilitating protein-protein interactions and subsequent formation of signalling networks. These proteins recruit binding partners to a specific location inside the cell, and also regulate their activity. Adaptor protein Ruk/CIN85 and its structural and functional homologue CD2AP/CMS are important components of different regulatory pathways involved in control of cell proliferation, adhesion, invasion and survival, and, thus, can play a role in uterine carcinogenesis. In this work, we set out a comparative study of expression of Ruk/CIN85 and CD2AP/CMS at the level of mRNA and protein in intact uterine tissues, as well as in benign and malignant uterine tumors of different histological types. In most cases, an increase of expression levels of Ruk/CIN85 full-length form mRNA and protein, as well as CD2AP/CMS protein, were observed in uterine tumors, comparing with surrounding normal uterine tissues. Characteristic feature of conditionally normal uterine tissues, as well as benign uterine lesions, was an elevated content of high-molecular mass Ruk/CIN85 forms of 140 and $130 \mathrm{kDa}$, while an increased expression level of low-molecular mass 40 and $30 \mathrm{kDa}$ Ruk/CIN85 forms was observed in the malignant tissue samples. Our findings suggest that an abnormal expression patterns of adaptor proteins Ruk/CIN85 and CD2AP/CMS in uterine tumors, and, thus, the corresponding changes in the activity of downstream signalling pathways, might be involved in maintenance of the malignant phenotype.

Key words: tumorigenesis, adaptor proteins, Ruk/CIN85, CD2AP/CMS, benign and malignant uterine tumors.

Abbreviations: Ruk/CIN85, regulator of ubiquitous kinase/Cbl-interacting protein of $85 \mathrm{kDa}$; CD2AP/CMS, CD2 associated protein/Cas ligand with multiple SH3 domains; 
SH3 domain, Src homology 3 domain; PR, proline-rich; CC domain, C-terminal coiled-coil domain; RTK, receptor tyrosine kinase; PI3K, phosphoinositide 3-kinase; ERK/MAPK, extracellular signal-regulated kinase/mitogen-activated protein kinase; TGF- $\beta$, transforming growth factor beta; CAPZ, capping protein (actin filament) muscle Z-line; TXS, Triton $\mathrm{X}-100$ soluble fraction; TTP, total tissue protein fraction; PBS, phosphate buffered saline.

\section{INTRODUCTION}

Adaptor proteins are involved in regulation of diverse signalling processes that control cellular proliferation, differentiation, survival, vesicular trafficking, adhesion and motility [14]. These proteins contain a variety of protein-binding modules linking together protein-binding partners and facilitating a creation of larger signalling complexes. Thus, adaptor proteins are positioned to regulate cell signalling in a spatial and temporal fashion [12].

Ruk/CIN85 and CD2AP/CMS belong to a family of ubiquitously expressed adaptor molecules. Different combinations of promoter utilization and splicing events create multiple ruk/cin85 transcripts in various tissues and cell lines, and expression of some of these transcripts is regulated during development [3].In contrast, CD2AP/CMS is expressed as a single transcript that corresponds to mRNA encoding full-length form of Ruk/CIN85 with molecular mass of $85 \mathrm{kDa}[17,34]$.

The overall domain organization of Ruk/CIN85 and CD2AP/CMS is identical; they share $39 \%$ identity and $54 \%$ similarity in their amino acid sequences [8]. Both molecules are composed of three $\mathrm{N}$-terminal $\mathrm{SH} 3$ domains, followed by a proline-rich region (providing binding sites for $\mathrm{SH} 3$ domain-containing proteins), an unstructured region of approximately 160 residues, enriched in Ser/Thr and C-terminal coil-coiled domain mediating homotypic and heterotypic interactions [17, 34]. The SH3 domains share similarities among themselves and between family members, and their overlapping functions were identified $[8,14,33]$.

Ruk/CIN85 plays a role in various biological processes including control of receptor tyrosine kinase signalling [1, 9, 18, 27, 28, 32], rearrangement of actin cytoskeleton [30], neuronal and T cell apoptosis [5, 15, 26], herpes simplex virus 1 infection [21], adhesion [30] and invasion [25]. Overexpression of Ruk/CIN85 full-length form induces apoptotic cell death of primary neurons in culture $[2,15]$. However, shorter molecular forms of Ruk/CIN85 block the pro-apoptotic effect of Ruk/CIN85, suggesting that expression of different combinations of Ruk/CIN85 proteins in cells could be involved in the regulation of their survival and other intracellular processes [2, 15].

CD2AP/CMS is required for rapid activation of PI3K and ERK/MAPK pathways by TGF- $\beta$ [29]. Direct interactions between CD2AP/CMS, nephrin, and podocin, and between CD2AP/CMS and the podocyte-specific actin-bundling protein synaptopodin, are essential for slit diaphragm integrity [16]. CD2AP/CMS was shown to localize in highly dynamic actin structures at the leading edge of cells and membrane ruffles, and have a role in cytoskeleton polarization associated with the activation of $\mathrm{T}$ cell receptors [10]. CD2AP/CMS associates with potassium-iodide-sensitive filamentous actin (F-actin) in the lysates of purified kidney glomeruli [37]. CD2AP/CMS associates with anillin, a component of the actin-rich cleavage furrow, at the midbody during cell division [23]. At the molecular level, CMS is linked to F-actin indirectly by binding to the focal adhesion protein p130Cas and Src-family kinases, cortactin, and the CAPZA and CAPZB heterodimer. Moreover, Ruk/CIN85 has been also shown to bind the focal adhesion kinase [14].

ISSN 1996-4536 • Біологічні Студії / Studia Biologica • 2009 • Том 3/№3 • С. 5-16 
Some proteins have been demonstrated to interact with both Ruk/CIN85 and CD2AP/CMS, whereas others bind only one of them. Experimental data obtained by different groups have shown similar functions $[8,14]$ as well as antagonizing functions [34] for Ruk/CIN85 and CD2AP/CMS. It was reported that (Ruk/CIN85)/(CD2AP/CMS) balance is involved in the orchestrated signal transduction response [34].

Tumorigenesis is a multistep process that involves genetic alterations driving a progressive transformation of normal cells to the malignant phenotype. It is characterized by a dysregulation of numerous molecular pathways, such as cell cycle progression, angiogenesis, and apoptosis, that represent rational targets for the development of selective therapeutic approaches.

Uterine cervix and uterine corpus carcinomas are a significant cause of death for women suffering from gynaecologic malignancies [31]. The aim of our study was to compare the expression levels of Ruk/CIN85 and CD2AP/CMS in tissue samples of uterine fibromyoma, cervical dysplasia, stromal tumors, endometrial hyperplasia, body cancer, cervical cancer, sarcoma, and conditionally normal uterus.

\section{MATERIALS AND METHODS}

Sample collection. Lesion samples with corresponding control samples were obtained from 31 women who underwent initial surgery at the Danylo Halytsky Lviv National Medical University. The diagnosis was verified upon clinical and/or pathological criteria. Based on these criteria, the samples were divided into several groups representing control tissue $(n=8)$, benign tumors (fibromyoma: $n=3$; cervical dysplasia: $n=1$; stromal tumor: $n=4$; endometrial hyperplasia: $n=2$ ), malignant tumors (body cancer: $n=12$; cervical cancer: $n=4$; sarcoma: $n=2$ ). The main clinical characteristics of patients are summarized in the Table. Just after removal, samples were macrodissected by the morphologist, rapidly frozen in liquid nitrogen, and stored at $-130^{\circ} \mathrm{C}$ until use.

Samples preparation. Triton $\mathrm{X}-100$ soluble (TXS) fraction was obtained by using lysis buffer (10 mM Tris-HCl, pH 7.5, 150 mM NaCl, 1\% Triton X-100, 5 mM EDTA, 50 mM $\mathrm{NaF}, 1 \mathrm{mM} \mathrm{Na} \mathrm{VO}_{4}, 5 \mathrm{mM}$ benzamidine, $1 \mathrm{mM} \mathrm{PMSF}, 10 \mu \mathrm{g} / \mathrm{ml}$ aprotinin, $10 \mu \mathrm{g} / \mathrm{ml}$ leupeptin, $1 \mu \mathrm{g} / \mathrm{ml}$ pepstatin). Total tissue protein (TTP) fraction was obtained using guanidine thiocyanate buffer (4 M GTC, $25 \mathrm{mM}$ sodium citrate, $\mathrm{pH} 7.0,0.5 \% \mathrm{~N}$-lauroylsarcosine, $0.1 \mathrm{M}$ 2-mercaptoethanol). GTC-extracts were centrifuged at $12,000 \mathrm{~g}$ for $30 \mathrm{~min}$ at $4^{\circ} \mathrm{C}$; phenol-chloroform interphase was precipitated with 2-propanol and protein pellets were dissolved in $50 \mathrm{mM}$ Tris, pH 6.8, 2\% SDS [6].

Northern blot-analysis. A modified protocol described by Chomczynski and Sacchi [7] was used. Briefly, uterine tissue $(100 \mathrm{mg})$ was homogenized in $2.0 \mathrm{ml}$ of a solution containing $4 \mathrm{M}$ guanidine thiocyanate, $25 \mathrm{mM}$ sodium citrate $(\mathrm{pH} 7.0), 0.5 \%$ sarcosyl, $0.1 \mathrm{M}$ 2-mercaptoethanol. Then, $0.2 \mathrm{ml}$ of $2 \mathrm{M}$ sodium acetate $(\mathrm{pH} 4.0), 2.0 \mathrm{ml}$ of phenol (water saturated) and $0.4 \mathrm{ml}$ of chloroform were added and the homogenate was mixed. Prior to centrifugation at $10,000 \mathrm{~g}$ for $20 \mathrm{~min}$, the solution was chilled on ice for $15 \mathrm{~min}$. After centrifugation and precipitation by isopropanol, the resulting RNA pellet was dissolved in $100 \%$ formamide and stored at $-70^{\circ} \mathrm{C}$ until use. Total RNA $(20 \mu \mathrm{g})$ was subjected to electrophoresis in denaturing formaldehyde $1.25 \%$ agarose gel, and then transferred onto Hybond-N nylon membrane („Amersham”). RNA was fixed by the ultraviolet cross-linking. The original 3E7 clone was used as a probe for Northern hybridization. 
SDS-PAGE and Western blot-analysis. Tissue extracts were prepared as described above, boiled in 2x Laemmli's sample buffer [19], and electrophoresed in gradient (5-18\%) SDS-polyacrylamide gel. Then proteins were electrophoretically transferred onto nitrocellulose membrane („Amersham”) in a buffer containing 25 mM Tris, 192.5 $\mathrm{mM}$ Glycine, $20 \%$ methanol at $250 \mathrm{~mA}$ for $2 \mathrm{hrs}$ [35]. After blocking with PBST (PBS/0.05\% Tween-20) containing 5\% dried fat-free milk, membranes were incubated with the anti-CD2AP (Santa Cruz Biotech., USA), anti-Ruk/SH3A or anti-Ruk/CC [22] (dilution 1:2,000 in blocking solution) primary antibodies, followed by incubation with secondary anti-mouse or anti-rabbit IgGs conjugated with horseradish peroxidase („Amersham"). The membrane was washed three times with PBST and twice with PBS, and subjected to ECL detection (Amersham Biosciences, USA). Monoclonal anti-Ruk/SH3A antibody raised against the first SH3A domain of Ruk/CIN85 recognizes full-length form of Ruk/CIN85. Polyclonal anti-Ruk/CC antibodies raised against C-terminal coiled-coil region of Ruk/CIN85 recognize all Ruk/CIN85 multiple molecular forms [22]. Protein expression was quantified by using GEL-PRO Analyzer 32.

\section{RESULTS AND DISCUSSION}

Study of ruk/cin85 transcripts expression in benign tumors and malignant uterine samples. Samples of conditionally normal tissues and uterine tumors were analyzed by the Northern blot analysis. The expression levels of ruk/cin85 mRNA transcripts were normalized according to $18 \mathrm{~S}$ rRNA.

The main $3.5 \mathrm{~kb}$ ruk/cin85 transcript which encodes the full-length form of Ruk/ CIN85 with molecular mass of $85 \mathrm{kDa}$ was detected in the samples of total RNA isolated from uterine tissues. In the analyzed samples, both $2.5 \mathrm{~kb}\left(r u k_{m}\right)$ and $1.5 \mathrm{~kb}\left(r u k_{s}\right)$ transcripts were expressed at significantly lower level in comparison with $3.5 \mathrm{~kb}\left(r u k_{l}\right)$ transcript. High expression level of $3.5 \mathrm{~kb}$ ruk/cin85 transcript was revealed in analyzed benign uterine tumors (Fig. 1, Table). In most cases, an increase of $3.5 \mathrm{~kb}$ ruk/cin85 transcript expression level was observed in malignant uterine body and uterine cervix samples in comparison with the surrounding normal uterine tissue (Fig. 1, Table).

Expression of specific genes is not always followed by synthesis of functional proteins. Therefore, at the next stage we analyzed the expression patterns of Ruk/CIN85 multiple molecular forms in TXS and TTP fractions of conditionally normal uterine tissues, as well as uterine lesions. Notably, TTP extraction gives a possibility to solubilize additional proteins that are tightly associated with cell cytoskeleton and nuclear matrix.

Multiple immunoreactive bands, which correspond to proteins with apparent molecular mass of 140, 130, 85, 56, 40 and $34 \mathrm{kDa}$, were revealed in TXS fraction of benign uterine lesions using polyclonal anti-Ruk/CC antibodies (Fig. 2). According to current experimental data, some of these multiple molecular forms of Ruk/CIN85 detected with antiRuk/CC antibodies (full-length form - $85 \mathrm{kDa}$, a form without first SH3A domain - $70 \mathrm{kDa}$, and a form without two SH3 domains - $56 \mathrm{kDa}$ ) could be a result of alternative splicing of Ruk/CIN85 pre-mRNA transcript. Other forms may be a result of posttranslational modifications caused by the ubiquitilation (140,130 and $100 \mathrm{kDa}$ ) and limited proteolysis (40 and $34 \mathrm{kDa}$ ) [36]. High content of the full-length form was revealed in TXS fraction of uterine benign lesion samples (Fig. 2, Table). The characteristic feature of benign uterine lesions was high content of p140 and p130 forms. Interestingly, Ruk/CIN85 multiple molecular

ISSN 1996-4536 • Біологічні Студії / Studia Biologica • 2009 • Том 3/№3 • С. 5-16 
Benign tumors

\begin{tabular}{|c|c|c|}
\hline$f$ & $f$ & $s t$ \\
\hline \multirow{2}{*}{} & $\varrho$ & $\curvearrowleft$ \\
\hline 1 & 2 & 3 \\
\hline
\end{tabular}

Body cancer

\begin{tabular}{|c|c|c|c|c|c|c|c|}
\hline $\mathrm{C}$ & $\mathrm{t}$ & $\mathrm{C}$ & $\mathrm{t}$ & $\mathrm{C}$ & $\mathrm{t}$ & $\mathrm{C}$ & $\mathrm{t}$ \\
\hline$\stackrel{\mathscr{N}}{\Delta}$ & ָั & 吉 & $\stackrel{m}{\square}$ & జి & ָొ & ๓ூ & 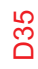 \\
\hline 1 & 2 & 3 & 4 & 5 & 6 & 7 & 8 \\
\hline
\end{tabular}

\section{Cervical cancer}

\begin{tabular}{|c|c|c|}
\hline $\mathrm{c}$ & $\mathrm{t}$ & $\mathrm{t}$ \\
\hline 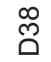 & ঙ্లి & ڤ్ \\
\hline 1 & 2 & 3 \\
\hline
\end{tabular}
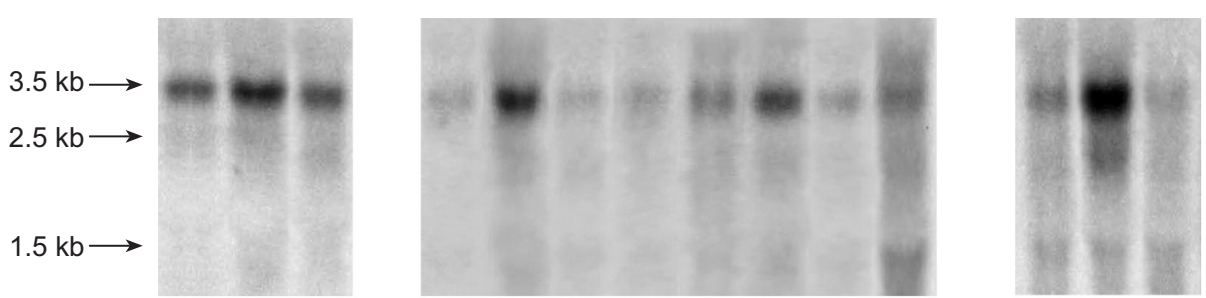

ruk/cin85
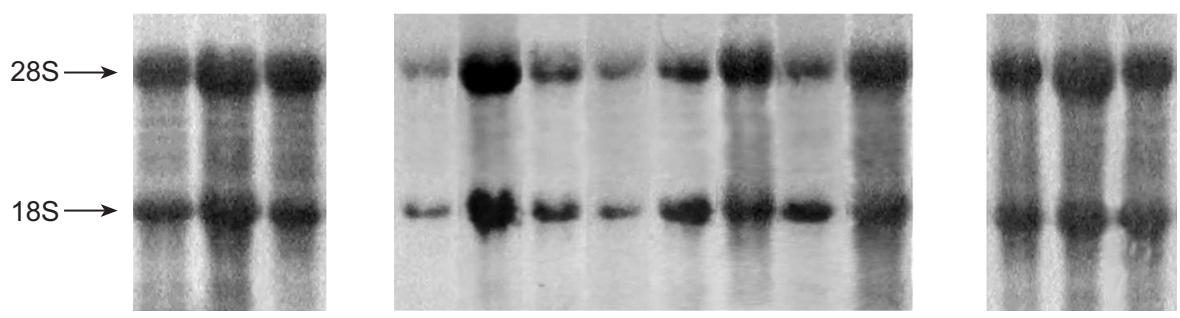

RNA
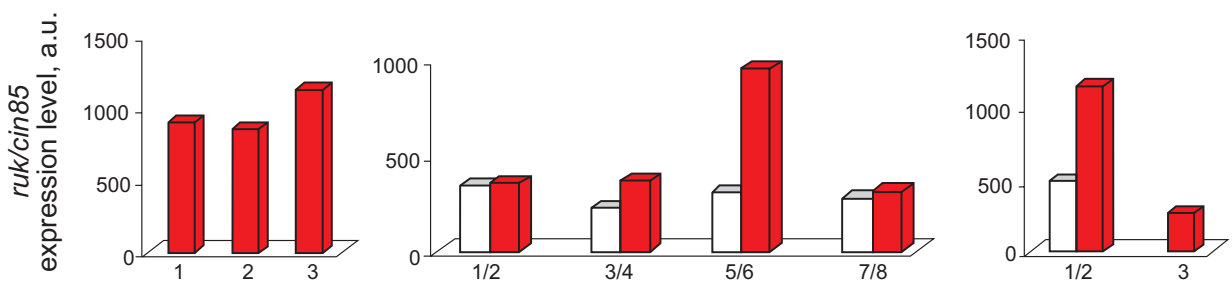

Fig. 1. Northern blot-analysis of ruk/cin 85 mRNA transcripts in samples of uterine lesions: benign tumors, body cancer, cervical cancer. Expression level of $3.5 \mathrm{~kb} r u k / c i n 85$ transcript is presented in arbitrary units (a.u.). $f$ - fibromyoma, st - stromal tumor, $c$ - normal uterine tissue, $t$ - tumor

Рис. 1. Нозерн-блот-аналіз мРНК транскриптів ruk/cin85 у зразках пухлин матки: доброякісні пухлини, рак тіла, рак шийки. Рівень експресії ruk/cin85 транскрипту розміром 3,5 тпн представлений в умовних одиницях (а.и.). $\mathrm{f}$ - фіброміома, st - стромальна пухлина, c - контроль, $\mathrm{t}$ - пухлина

forms pattern of benign lesions was very similar to that detected in the conditionally normal uterine tissues (p140, p130, p85, p56, p40 and p34 forms). The same patterns of expression of Ruk/CIN85 multiple molecular forms were detected in the TXS fraction of most uterine body and cervical tumor samples, however, some level of polymorphism of p140 content was present (Fig. 2).

Polymorphism of Ruk/CIN85 full-length form expression was revealed in the TTP fraction of the benign uterine lesions. An increase of p85 content in the TTP fraction was detected in the uterine body tumors, as well as in uterine cervix carcinoma samples in 


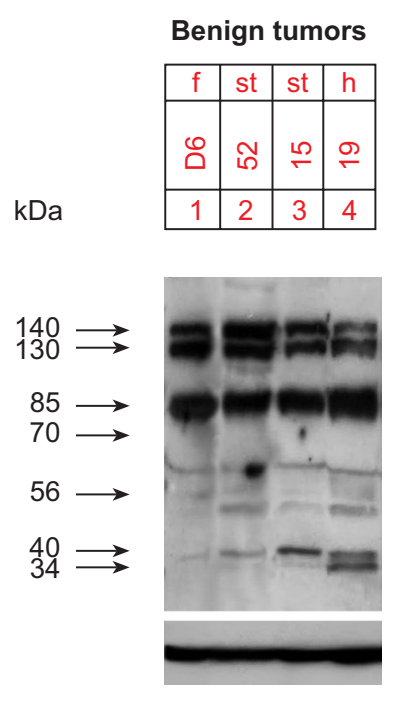

\begin{tabular}{|c|c|c|c|c|c|}
\hline \multicolumn{6}{|c|}{ Body cancer } \\
\hline C & $\mathrm{t}$ & $\mathrm{t}$ & $t$ & $\mathrm{t}$ & $t$ \\
\hline Б̄ & חొ & $\mathcal{F}$ & $\stackrel{\infty}{\infty}$ & $\widehat{0}$ & g \\
\hline 1 & 2 & 3 & 4 & 5 & 6 \\
\hline
\end{tabular}

\section{Cervical cancer}

\begin{tabular}{|c|c|c|}
\hline $\mathrm{t}$ & $\mathrm{t}$ & $\mathrm{t}$ \\
\hline ભ & ஹू & $\widehat{N}$ \\
\hline 1 & 2 & 3 \\
\hline
\end{tabular}

IB:
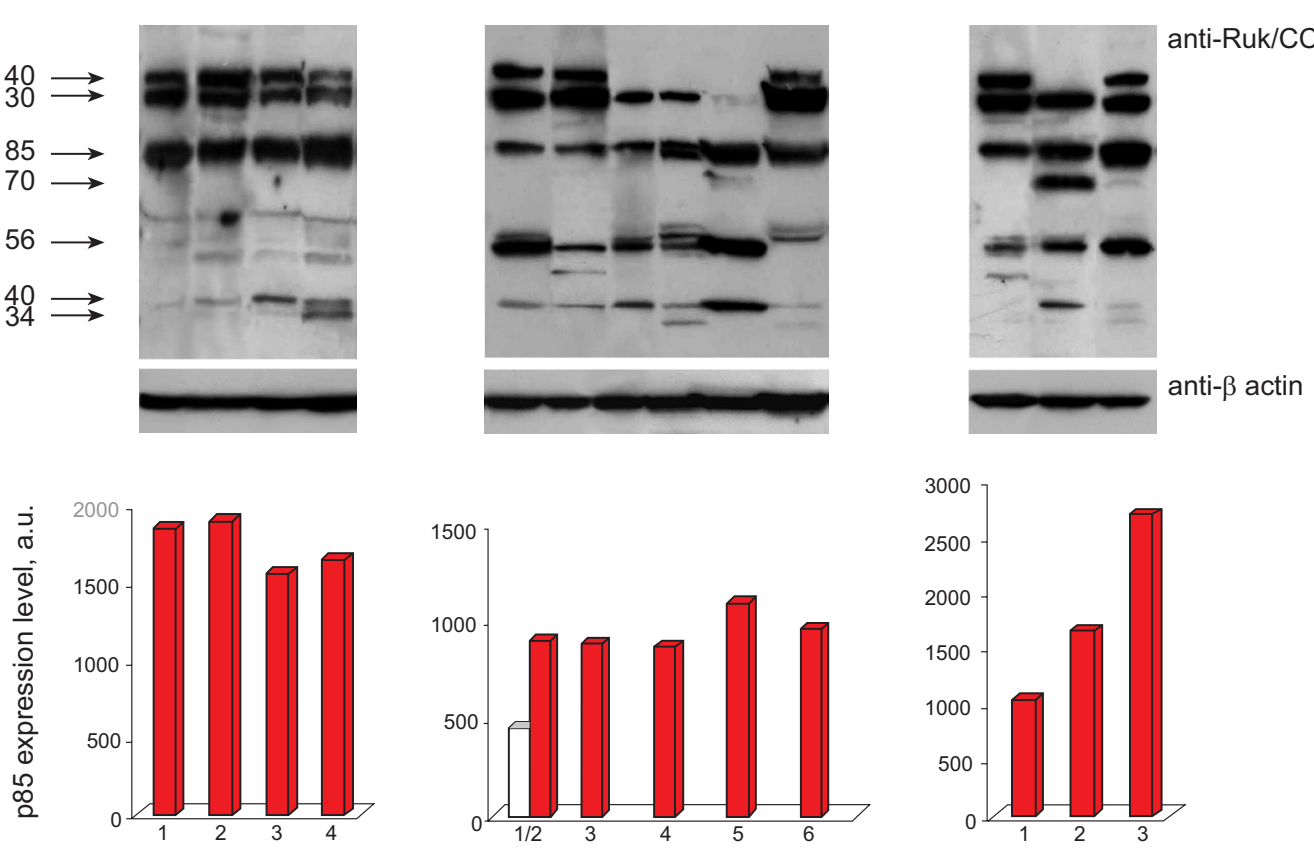

Fig. 2. Ruk/CIN85 content in the TXS fraction extracted from uterine lesions: benign tumors, body cancer, cervical cancer. p85 content is presented in arbitrary units (a.u.). IB - immunoblotting; $f$ - fibromyoma, st - stromal tumor, $\mathrm{h}$ - endometrial hyperplasia, $\mathrm{c}$ - normal tissue, $\mathrm{t}$ - tumor

Рис. 2. Вміст Ruk/CIN85 у TXS фрракції, екстрагованої з пухлин матки: доброякісні пухлини, рак тіла, рак шийки. Вміст р85 представлений в умовних одиницях (а.u.). IB - імуноблотинг; f - фіброміома, st - стромальна пухлина, $\mathrm{h}$ - гіперплазія ендометрію, с - контроль, $\mathrm{t}$ - пухлина

comparison with corresponding control samples. By using anti-Ruk/CC antibodies in Western-blot-analysis, the immunoreactive bands corresponding to proteins with apparent molecular mass of $140,130,100,85$, and $50 \mathrm{kDa}$ were detected in samples of the normal uterine tissue. The patterns of Ruk/CIN85 multiple molecular forms in analyzed samples of the uterine cancer (body of uterus) differ from that in normal uterine tissues, by a predominant decrease in content of high-molecular mass forms (p140, p130, p100) and the appearance of p70 form. An additional feature of Ruk/CIN85 patterns in the uterine body carcinoma was an increase in content of low-molecular mass forms ( $p 40$, p34). Similar peculiarities in the patterns of Ruk/CIN85 expression were revealed in control and cancer uterine cervix samples (Fig.3). 
Benign tumors

\begin{tabular}{|c|c|c|}
\hline$f$ & $f$ & $s t$ \\
\hline 巳 & $\bullet$ & ๑ \\
\hline 1 & 2 & 3 \\
\hline
\end{tabular}
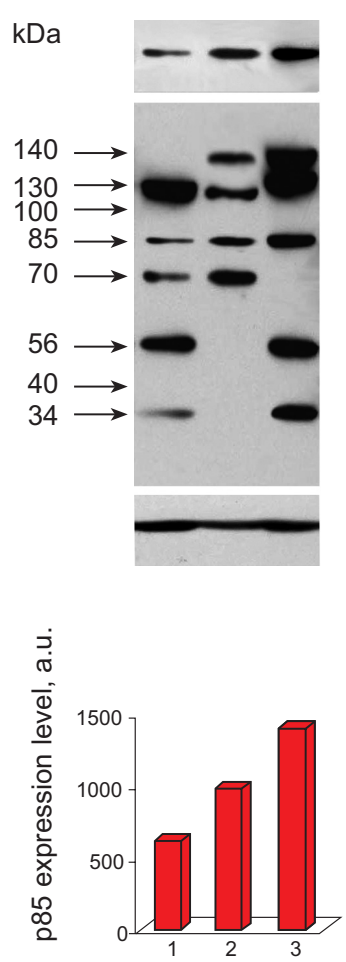

\begin{tabular}{|c|c|c|c|c|c|c|c|}
\hline \multicolumn{8}{|c|}{ Body cancer } \\
\hline c & $t$ & c & $\mathrm{t}$ & $\mathrm{C}$ & $\mathrm{t}$ & c & $\mathrm{t}$ \\
\hline $\begin{array}{l}\text { N } \\
\text { D }\end{array}$ & ָั & 吉 & $\stackrel{?}{\Delta}$ & ָ̃ & ָొ & ט & مِ \\
\hline 1 & 2 & 3 & 4 & 5 & 6 & 7 & 8 \\
\hline
\end{tabular}

Cervical cancer

\begin{tabular}{|c|c|c|c|}
\hline C & $\mathrm{t}$ & $\mathrm{t}$ & $\mathrm{t}$ \\
\hline 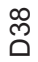 & ్ֻలి & ఇి & ్ֻ \\
\hline 1 & 2 & 3 & 4 \\
\hline
\end{tabular}
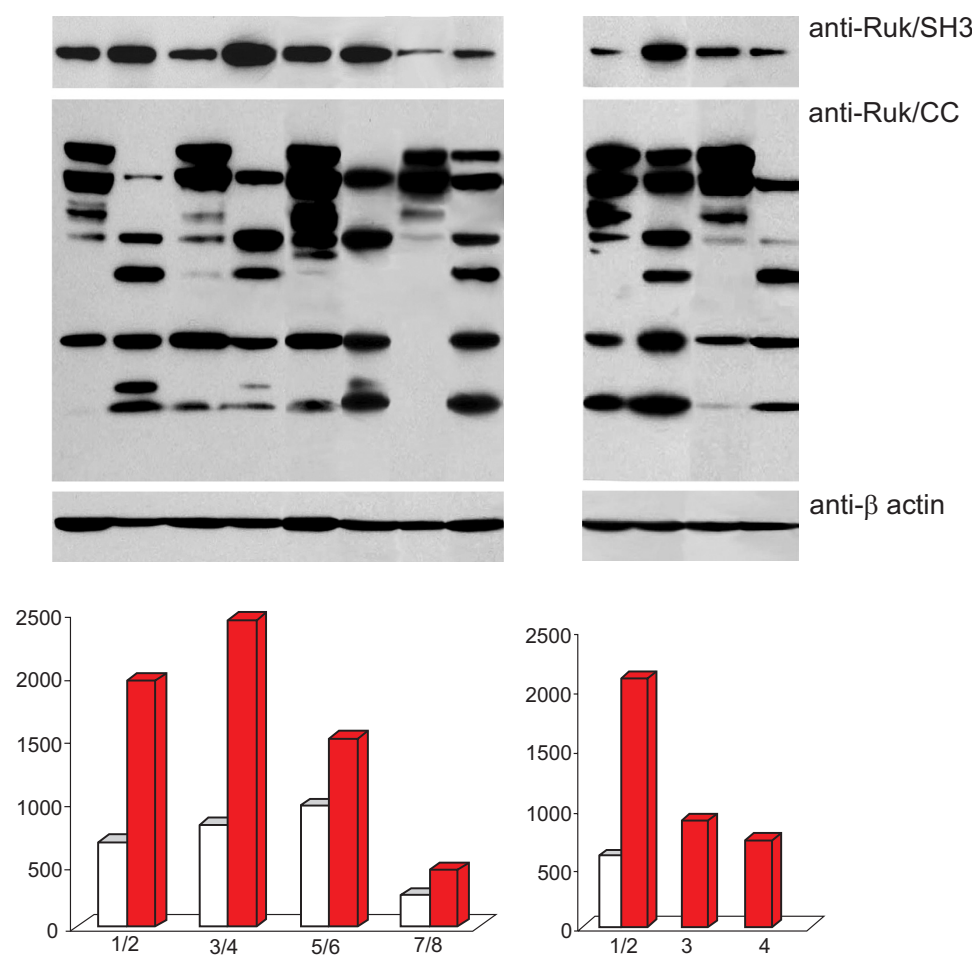

Fig. 3. Ruk/CIN85 content in the TTP fraction extracted from uterine lesions: benign tumors, body cancer, cervical cancer. p85 content is presented in arbitrary units (a.u.). IB - immunoblotting; $f$ - fibromyo$\mathrm{ma}, \mathrm{st}$ - stromal tumor, $\mathrm{h}$ - endometrial hyperplasia, $\mathrm{c}$ - normal tissue, $\mathrm{t}$ - tumor

Pис. 3. Вміст Ruk/CIN85 у TTP фракції, екстрагованої з пухлин матки: доброякісні пухлини, рак тіла, рак шийки. Вміст р85 представлений в умовних одиницях (а.u.). IB - імуноблотинг; $f$ - фіброміома, st - стромальна пухлина, $\mathrm{h}$ - гіперплазія ендометрію, c - контроль, $\mathrm{t}$ - пухлина

Since adaptor protein CD2AP/CMS is a structural and functional homologue of Ruk/ CIN85, we investigated an expression level of CD2AP/CMS protein in uterine lesions in comparison with adjacent normal tissues. A comparatively high expression level of CD2AP/ CMS was detected in the benign tumors. Similarly to Ruk/CIN85, up-regulation of CD2AP/ CMS was detected in most samples of the uterine body and uterine cervix tumors.

Although the present study has certain limitations, the obtained results demonstrate the same directivity in Rukl/CIN85 and CD2AP/CMS expression levels in most uterine carcinomas studied in comparison with surrounding conditionally normal tissues. At the 
Benign tumors

\begin{tabular}{|c|c|c|}
\hline$f$ & $f$ & st \\
\hline t & $\varrho$ & $\Re$ \\
\hline 1 & 2 & 3 \\
\hline
\end{tabular}
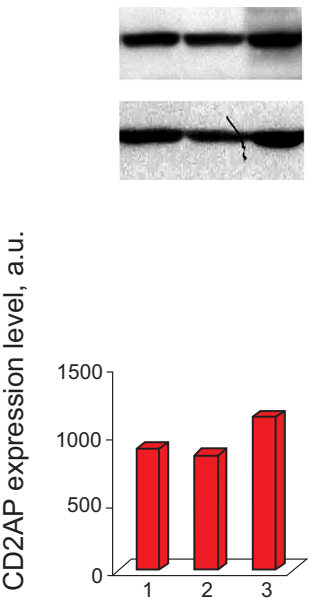

Body cancer

\begin{tabular}{|c|c|c|c|c|c|c|c|}
\hline c & $\mathrm{t}$ & C & $\mathrm{t}$ & $C$ & $\mathrm{t}$ & C & $\mathrm{t}$ \\
\hline ผี & 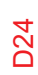 & \& & $\stackrel{m}{\square}$ & ฉ్ & గ్లి & $\overline{\tilde{\rho}}$ & مొ \\
\hline 1 & 2 & 3 & 4 & 5 & 6 & 7 & 8 \\
\hline
\end{tabular}
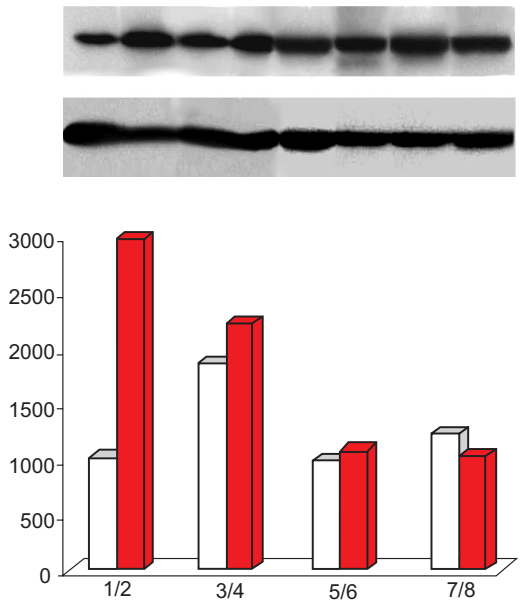

Cervical cancer

\begin{tabular}{|c|c|c|c|}
\hline C & $\mathrm{t}$ & $\mathrm{t}$ & $t$ \\
\hline $\begin{array}{l}\infty \\
\tilde{m} \\
0\end{array}$ & ڤ్లి & ฉి & ল \\
\hline 1 & 2 & 3 & \\
\hline
\end{tabular}

IB:
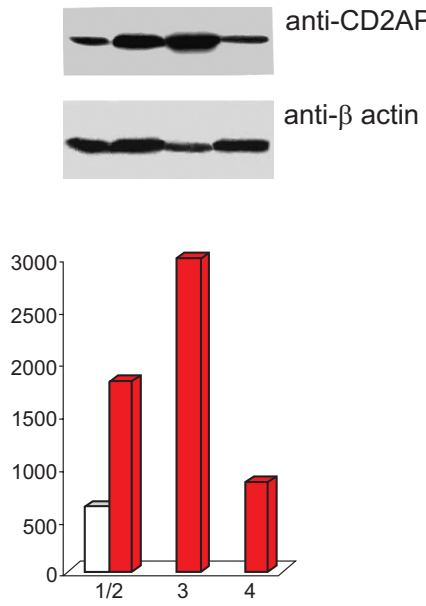

Fig. 4. CD2AP/CMS content in the TTP fraction extracted from uterine lesions: benign tumors, body cancer, cervical cancer. CD2AP/CMS content is presented in arbitrary units (a.u.). IB - immunoblotting; $f$ fibromyoma, st - stromal tumor, c - normal tissue, $\mathrm{t}$ - tumor

Pис. 4. Вміст CD2AP/CMS у TTP фрракції, екстрагованої з пухлин матки: доброякісні пухлини, рак тіла, рак шийки. Вміст CD2AP/CMS представлений в умовних одиницях (а.u.). IB - імуноблотинг; f фіброміома, st - стромальна пухлина, c - контроль, $\mathrm{t}$ - пухлина

same time, there is an essential heterogeneity both in the fold of adaptor proteins elevation and their ratio between different samples pairs. These features may be related to the tumors type and grade as well as sensitivity to anti-tumor therapy that needs further investigation.

\section{CONCLUSION}

Numerous molecular studies showed that PI3K-AKT-mTOR, RAS-MEK-ERK and SRC-FAK signalling pathways are implicated in the development of uterine malignancies $[4,11,13,24,38]$. Taking into account that (Ruk/CIN85)/(CD2AP/CMS) adaptor proteins are key components of these signalling networks, we suggest that their abnormal expression patterns in uterine tumors might be involved in the maintenance of malignant phenotype and, additionaly, may represent a novel molecular target for chemotherapeutics.

\section{ACKNOWLEDGMENT}

This work was supported by grant of WUBMRC (2006), and was performed in frames of the program „Modern biotechnologies and human environment”. 
Table. Clinical data, ruk/cin85 transcripts expression and (Ruk/CIN85)/(CD2AP/CMS) proteins content in the TXS and TTP fractions

Таблиця. Клінічні дані пацієнтів, рівень експресії транскриптів ruk/cin85 і вміст білків (Ruk/ CIN85)/(CD2AP/CMS) у фракціях TXS і TTP

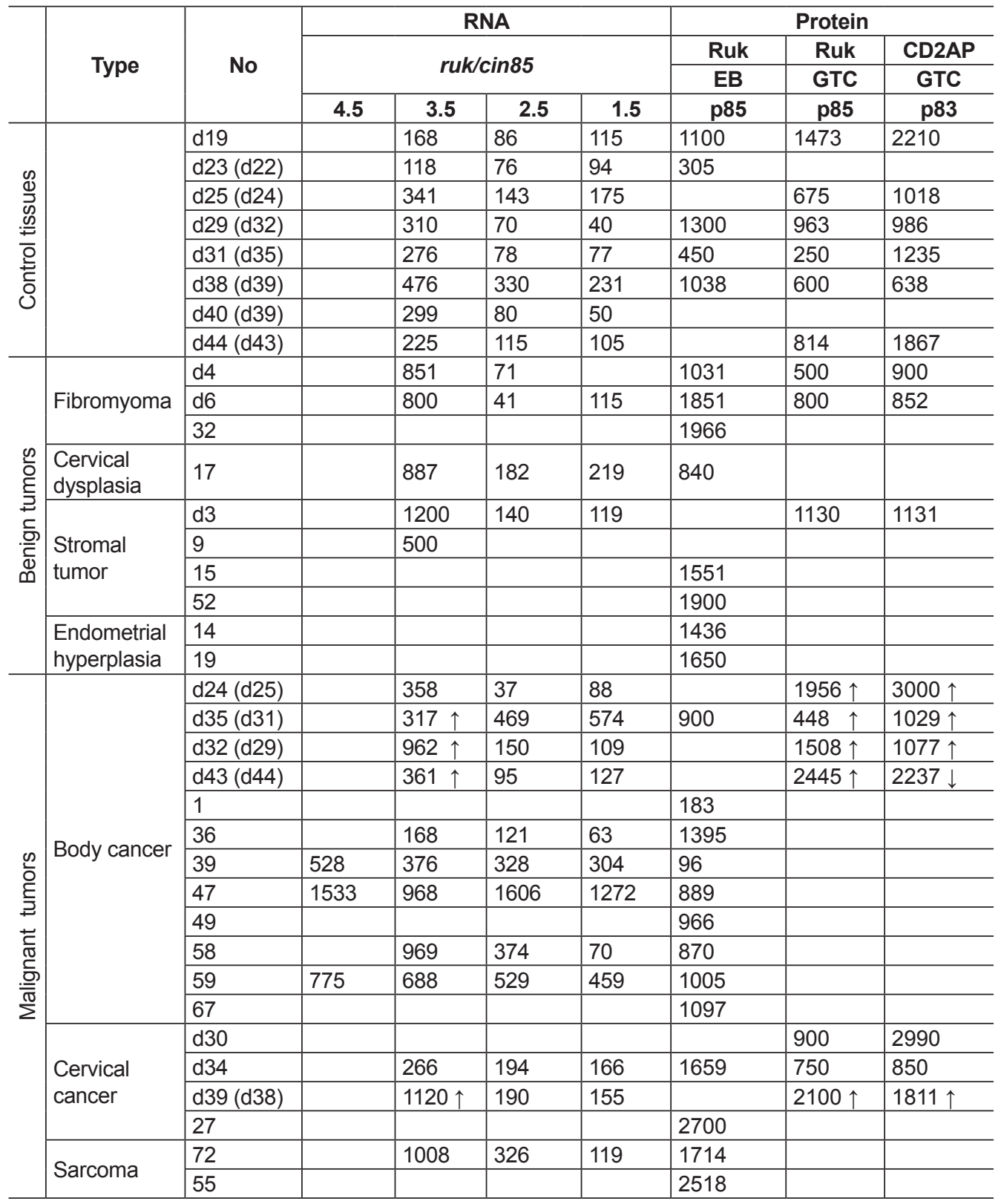

Levels of transcript expression and protein content are presented in the arbitrary units.

$\uparrow \downarrow-$ up- or down-regulation of Ruk/CIN85 in uterine tumor in comparison with conditionally normal tissue 
1. Aissouni Y., Zapart G., lovanna J.L. et al. CIN85 regulates the ability of MEKK4 to activate the p38 MAP kinase pathway. BBRC, 2005; 338: 808-814.

2. Borthwick E., Korobko I., Luke C. et al. Multiple Domains of Ruk/CIN85/SETA/CD2BP3 are involved in interaction with p85a regulatory subunit of PI 3-kinase. J. Mol. Biol, 2004; 343: 1135-1146.

3. Buchman V., Luke C., Borthwick E. et al. Organization of the mouse Ruk locus and expression of isoforms in mouse tissues. Gene, 2002; 295: 13-17.

4. Castellvi J., Garcia A., Ruiz-Marcellan C. et al. Cell signaling in endometrial carcinoma: phosphorylated 4E-binding protein-1 expression in endometrial cancer correlates with aggressive tumors and prognosis. Hum. Pathol, 2009; 40(10): 1418-1426.

5. Chen B., Borinstein S.C., Gillis J. et al. The glioma-associated protein SETA interacts with AIP1/Alix and ALG-2 and modulates apoptosis in astrocytes. J. Biol. Chem, 2000; 275: 19275-19281.

6. Chomczynski P. A reagent for the single-step simultaneous isolation of RNA, DNA and proteins from cell and tissue samples. Biotechniques, 1993; 15: 532-4, 536-7.

7. Chomczynski P., Sacchi N. Single-step method of RNA isolation by acid guanidinium thiocyanate-phenol-chloroform extraction. Anal. Biochem, 1987; 162(1): 156-159.

8. Dikic I. CIN85/CMS family of adaptor molecules. FEBS Lett, 2002; 529: 110-115.

9. Dikic l., Giordano S. Negative receptor signalling. Curr. Opin. Cell Biol, 2003; 15: 128-135.

10. Dustin M.L., Olszowy M.W., Holdorf A.D. et al. A novel adaptor protein orchestrates receptor patterning and cytoskeletal polarity in T-cell contacts. Cell, 1998; 94(5): 667-677.

11. Ejskjaer K., Sørensen B.S., Poulsen S.S. et al. Expression of the epidermal growth factor system in endometrioid endometrial cancer. Gynecol. Oncol, 2007; 104(1): 158-167.

12. Flynn D.C. Adaptor protein. Oncogene, 2001; 20: 6270-6272.

13. Gabriel B., zur Hausen A., Stickeler E. et al. Weak expression of focal adhesion kinase (pp125FAK) in patients with cervical cancer is associated with poor disease outcome. Clin. Cancer Res, 2006;12(8): 2476-2483.

14. Gaidos G., Soni S., Oswald D.J. et al. Structure and function analysis of the CMS/CIN85 protein family identifies actin-bundling properties and heterotypic-complex formation. J. Cell Sci, 2007; 120(14): 2366-2377.

15. Gout I., Middleton G., Adu J. et al. Negative regulation of PI 3-kinase by Ruk, a novel adaptor protein EMBO J, 2000; 19(15): 4015-4025.

16. Johnson R.I., Seppa M.J., Cagan R.L. The Drosophila CD2AP/CIN85 orthologue Cindr regulates junctions and cytoskeleton dynamics during tissue patterning. J. Cell Biol, 2008; 80(6): 1191-1204.

17. Kirsch K., Georgescu M., Ishimaru S., Hanafusa H. CMS: an adapter molecule involved in cytoskeletal rearrangements. Proc. Natl. Acad. Sci. USA, 1999; 96(11): 6211-6216.

18. Kowanetz K., Husnjak K., Höller D. et al. CIN85 Associates with Multiple Effectors Controlling Intracellular Trafficking of Epidermal Growth Factor Receptors. J. Mol. Biol, 2004; 15: 3155-3166.

19. Laemmli U.K. Cleavage of structural proteins during the assembly of the head of bacteriophage T4. Nature, 1970; 227: 680-684.

20. Lee K.H., Dinner A.R., Tu C. et al. The Immunological Synapse Balances T Cell Receptor Signalling and Degradation. Science, 2003; 302: 1218-1222.

21. Liang Y., Kurakin A., Roizman B. Herpes simplex virus 1 infected cell protein 0 forms a complex with $\mathrm{CIN85}$ and $\mathrm{Cbl}$ and mediates the degradation of EGF receptor from cell surfaces. Proc. Natl. Acad. Sci. USA, 2005; 102: 5838-5843.

22. Mayevska O., Shuvayeva H., Igumentseva N. et al. Expression of adaptor protein Ruk/CIN85 isoforms in cell lines of various tissue origins and human melanoma. Exp. Oncol, 2006; 28: 275-281.

23. Monzo P., Gauthier N.C., Keslair F. et al. Clues to CD2-associated protein involvement in cytokinesis. Mol. Biol. Cell, 2005; 16(6): 2891-2902.

24. Mori N., Kyo S., Sakaguchi J. et al. Concomitant activation of AKT with extracellular-regulated kinase 1/2 occurs independently of PTEN or PIK3CA mutations in endometrial cancer and may be associated with favorable prognosiss. Cancer Sci, 2007; 98(12): 1881-1888.

25. Nam J.M., Onodera Y., Mazaki Y. et al. CIN85, a Cbl-interacting protein, is a component of AMAP1mediated breast cancer invasion machinery. EMBO J, 2007; 26(3): 647-656.

26. Narita T., Nishimura T., Yoshizaki K., Taniyama T. CIN85 associates with TNF receptor 1 via Src and modulates TNF-a-induced apoptosis. Exp. Cell Res, 2005; 304: 256-264.

27. Petrelli A., Gilestro G.F., Lanzardo S. et al. The endophilin-CIN85-Cbl complex mediates ligand-dependent downregulation of c-Met. Nature, 2002; 416: 187-190. 
28. Sakakibara T., Nemoto Y., Nukiwa T., Takeshima H. Identification and characterization of a novel Rho GTPase activating protein implicated in receptor-mediated endocytosis. FEBS Lett, 2004; 566: 294-300.

29. Schiffer M., Mundel P., Shaw A.S., Böttinger E.P. A novel role for the adaptor molecule CD2-associated protein in transforming growth factor-beta-induced apoptosis. J. Biol. Chem, 2004; 279(35): 37004-37012.

30. Schmidt M., Chen B., Randazzo L., Bogler O. SETA/CIN85/Ruk and its binding partner AIP1 associate with diverse cytoskeletal elements, including FAKs, and modulate cell adhesion. J. Cell Sci, 2003; 116: 2845-2855.

31. Schwartz L.A. Cervical cancer: disease prevention and informational support. Can. Oncol. Nurs. J, 2009; 19(1): 6-9.

32. Soubeyran P., Kowanetz K., Szymkiewicz I. et al. Cbl-CIN85-endophilin complex mediates ligand-induced downregulation of EGF receptors. Nature, 2002; 416(14): 183-186.

33. Tibaldi E., Reinherz E. CD2BP3, CIN85 and the structurally related adaptor protein CMS bind to the same CD2 cytoplasmic segment, but elicit divergent functional activities. Int. Immunol, 2003; 15(3): 313-329.

34. Tossidou I., Kardinal Ch., Peters I. et al. CD2AP/CIN85 Balance Determines Receptor Tyrosine Kinase Signalling Response in Podocytes. J. Biol. Chem, 2007; 282: 7457-7464.

35. Towbin H., Staehelin T., Gordon J. Electrophoretic transfer of proteins from polyacrylamide gels to nitrocellulose sheets: Procedure and some applications. Proc. Natl. Acad. Sci. USA, 1979; 76: 4350-4354.

36. Verdier F., Valovka T., Zhyvoloup A. et al. Ruk is ubiquitinated but not degraded by the proteasome. Eur. J. Biochem, 2002; 269(14): 3402-3408.

37. Yuan H., Takeuchi E., Salant D.J. Podocyte slit-diaphragm protein nephrin is linked to the actin cytoskeleton. Am. J. Physiol. Renal. Physiol, 2002; 282(4): 585-591.

38. Zhang X.Y., Zhang H.Y., Zhang P.N. et al. Elevated phosphatidylinositol 3-kinase activation and its clinicopathological significance in cervical cancer. Eur. J. Obstet. Gynecol. Reprod. Biol, 2008; 139(2): 237-244.

\title{
ПОРІВНЯЛЬНЕ ДОСЛІДЖЕННЯ ЕКСПРЕСІЇ АДАПТЕРНИХ БІЛКІВ RUК/CIN85 TA CD2АР/СМS У НОРМАЛЬНИХ I ПУХЛИННИХ ТКАНИНАХ МАТКИ ЛЮДИНИ
}

\author{
О. І. Басараба', Я. П. Бобак², Г. Ю. Шуваєва", \\ О. М. Маєвська ${ }^{2}$, Н. І. Ігуменцева ${ }^{2}$, С. М. Марченко1, \\ Н. А. Володько \\ ${ }^{3}$ Львівський національний медичний університет ім. Данила Галицького \\ вул. Пекарська, 69, Львів 79010, Україна \\ ${ }^{4}$ Кардіфрфський університет, Кардіфрф, Велика Британія
}

${ }^{1}$ /нститут біохімії ім. О. В. Палладіна НАН України, вул. Леонтовича, 9, Київ 01601, Україна ${ }^{2} /$ нститут біології клітини НАН України, вул. Драгоманова, 14-16, Львів 79005, Україна

Адаптерні білки відіграють важливу роль у білково-білкових взаємодіях, що забезпечують формування сигнальних мереж. Ці білки не лише залучають зв'язувальні білки-партнери до специфічних компартментів усередині клітини, але також регулюють їхню активність. Адаптерний білок Ruk/CIN85 та його структурний і функціональний гомолог CD2AP/CMS є важливими компонентами численних регуляторних шляхів, залучених до контролю проліферації, адгезії, інвазії та виживання клітин, і тому вони можуть відігравати важливу роль у канцерогенезі матки. У цій роботі представлено результати порівняльного дослідження експресії Ruk/CIN85 та CD2AP/CMS як на рівні мРНК, так і на рівні білка, в інтактних тканинах матки та в доброякісних і злоякісних пухлинах матки різного гістологічного типу. У більшості випадків виявлено зростання рівнів експресії мРНК і білка повнорозмірної фрорми Ruk/CIN85 та білка CD2AP/CMS у пухлинах матки порівняно з оточуючою їх нормальною тканиною. Характерною особливістю умовно нормальних тканин матки, як і доброякісних пухлин, є високий вміст високомо- 
лекулярних фрорм Ruk/CIN85 розміром 140 та 130 кДа, тоді як зростання вмісту низькомолекулярних форм Ruk/CIN85 розміром 40 та 30 кДа виявлено у зразках злоякісних пухлин. Результати проведених досліджень дають змогу припустити, що аномальна експресія адаптерних білків Ruk/CIN85 i CD2AP/CMS у пухлинах матки й відповідні можливі зміни фрункціональної активності розташованих нижче сигнальних шляхів можуть бути залучені до підтримання злоякісного фенотипу.

Ключові слова: канцерогенез, адаптерні білки, Ruk/CIN85, CD2AP/CMS, доброякісні та злоякісні пухлини матки.

\title{
СРАВНИТЕЛЬНОЕ ИЗУЧЕНИЕ ЭКСПРЕССИИ АДАПТЕРНЫХ БЕЛКОВ RUK/CIN85 И CD2AP/CMS В НОРМАЛЬНЫХ И ОПУХОЛЕВЫХ ТКАНЯХ МАТКИ ЧЕЛОВЕКА
}

\author{
О. И. Басараба', Я. П. Бобак², Г. Ю. Шуваева², \\ О. М. Маевская ${ }^{2}$ Н. И. Игуменцева ${ }^{2}$, С. Н. Марченко ${ }^{1}$ \\ Н. А. Володько ${ }^{3}$ В. Л. Бухман ${ }^{4}$ Л. Б. Дробот \\ ${ }^{3}$ Львовский национальный медицинский университет им. Данила Галицкого \\ ул. Пекарская, 69, Львов 79010, Украина \\ ${ }^{4}$ Кардифффский университет, Кардиффр, Великобритания
} 1 Институт биохимии им. А. В. Палладина НАН Украины, ул. Леонтовича, 9, Киев 01601, Украина ${ }^{2}$ Институт биологии клетки НАН Украины, ул. Драгоманова, 14-16, Львов 79005, Украина

Адаптерные белки играют важную роль в белок-белковых взаимодействиях, обеспечивающих формирование сигнальных сетей. Эти белки не только собирают вместе связующие белки-партнеры в специфических компартментах внутри клетки, но и вовлечены в регуляцию их активности. Адаптерный белок Ruk/CIN85 и его структурный и функциональный гомолог CD2AP/CMS являются важными компонентами многочисленных регуляторных путей, вовлеченных в контролирование пролиферации, адгезии, инвазии и выживания клеток и поэтому могут играть важную роль в канцерогенезе матки. В работе представлены результаты сравнительного изучения экспрессии Ruk/ CIN85 и CD2AP/CMS как на уровне мPHК, так и на уровне белка, в интактных тканях матки и в доброкачественных и злокачественных опухолях матки разных гистологических типов. В большинстве случаев обнаружено повышение уровней экспрессии мРНК и белка полноразмерной формы Ruk/CIN85 и белка CD2AP/CMS в опухолях матки по сравнению с окружающими их нормальными тканями матки. Характерной особенностью условно нормальных тканей матки, как и доброкачественных опухолей, является высокое содержание высокомолекулярных фрорм Ruk/CIN85 размером 140 и 130 кДа, в то время как повышенное содержание низкомолекулярных форм Ruk/CIN85 размером 40 и 30 кДа обнаружено в образцах злокачественных опухолей. Результаты проведенных исследований позволяют предположить, что аномальная экспрессия адаптерных белков Ruk/CIN85 и CD2AP/CMS в опухолях матки и возможные изменения активности находящихся ниже сигнальных путей могут быть вовлечены в поддержание злокачественного френотипа.

Ключевые слова: канцерогенез, адаптерные белки, Ruk/CIN85, CD2AP/CMS, доброкачественные и злокачественные опухоли матки.

Одержано: 16.10.2009

ISSN 1996-4536 • Біологічні Студії / Studia Biologica • 2009 • Том 3/№3 • С. 5-16 